\title{
REFLECTIONS ON JAVA AND ISLAM 1979-2010
}

\section{Mark Woodward}

Center for the Study of Religion and Conflict, Arizona State University, USA

\section{Abstract}

Since the late 1970s, technological developments, especially in communications and transportation, have contributed to growth of new modes of social interaction and, at the same time, to the strengthening of social bonds in geographically dispersed social groups and communities in Yogyakarta. Increased educational opportunities and especially the development of the Islamic university system have contributed to the development of a Muslim middle class and with it a Muslim consumer culture. There has also been a significant shift in the ways in which relationships between culture (kebudayaan) and religion (agama) are conceptualised. Elements of Javanese Muslim tradition including prayer meals (slametan) that were formerly called agama are now more commonly referred to as kebudayaan. This shift reflects and has contributed to the diminution of sectarian conflict. This cultural strategy is not always successful. It does, however, provide a basis for proactive measures to counter sectarian violence. This is evident in "cultural" festivals supported by the kraton (palace) in response to attacks on culturalperformance events by exclusivist religious groups.

[Sejak dekade 1970 an, kemajuan teknologi, utamanya dalam komunikasi dan transportasi, telah mengubah cara interaksi sosial masyarakat Yogyakarta dan, pada saat yang sama, semakin memperkokoh ikatan antar kelompok sosial. Semakin meningkatnya kesempatan belajar [sekolab], utamanya dengan berdirinya Universitas Islam, terbukti mendorong terciptanya kalangan 'Muslim kelas menengab' sekaligus konsumerisme yang melekat pada kalangan tersebut. Selain itu, terjadi pula perubahan konsep dalam 
menilai agama dan kebudayaan. Beberapa bentuk tradisi Islam Jawa, seperti slametan, yang dulunya dinilai sebagai ritual agama, saat ini hanya disebut sebagai kebudayaan. Perubahan ini menggambarkan dan babkan berperan dalam meminimalisir konflik sektarian, seperti terlihat jelas dalam acara festival "budaya" yang diadakan kraton sebagai respon terbadap pembubaran pementasan budaya oleh kalangan Muslim ekslusif.]

Keywords: social change, communication, transportation, education, kebudayaan, agama, Yogyakarta

\section{A. Introduction}

I first came to Yogyakarta in 1979 and have been researching and writing about Islam and Javanese culture here ever since. There have been many changes in Yogyakarta and in Indonesia more generally and there is much that remains as it was thirty some years ago. Today I do not want to indulge in personal reflections on continuity and change, reminisce nostalgically about the "good old days" or revel in the glories of developmentalism. I think that our purposes are served better by exploring, however briefly, the social and cultural dynamics that transformed Indonesia during a period of rapid social change. In this respect my comments are in the same spirit, if not nearly the same length or depth as those Selo Soemardjan made in his now classic, Social Changes in Yogyakarta about an equally significant period in Yogyanese and Indonesian history. ${ }^{1}$

Some of the most basic material and social changes that have taken place over the past thirty years are in the areas of communication, transportation and education. The rapid expansion of the middle class is unquestionably the most significant social change to take place during this period. These are not difficult to observe or to quantify. They are no less important for being obvious. There are also changes that cannot be attributed to economic and technological developments alone. Many of these are more difficult to locate because they are shifts in cultural and religious orientations that can be observed only indirectly. In assessing social, cultural and religious change in Yogyakarta over the 1962).

${ }^{1}$ S. Soemarjan, Social Changes in Yogyakarta (Ithaca: Cornell University Press, 
past three decades it is essential to be cognizant of the significance of the of the authoritarian, developmentalist "New Order" (1965-1998) and the dramatic change in the social, communications and religious environments that followed from its sudden and dramatic collapse in the "Reformasi" of 1998. ${ }^{2}$ What follows are tentative observations that might better be phrased as research questions. Some of these are explored in my recent book, Java, Indonesia and Islam. ${ }^{3}$ Others are observations and reflections on how Yogyakarta, Java and Indonesia have changed since the day that I first stepped off the train at Stasiun Tugu in January of 1979.

\section{B. Communications and Transportation}

In the late 1970s inter-personal communication was face to face to a much greater extent than it is today. Very few people have telephones or televisions. One could communicate with friends or family outside the city or by post or when there were urgent needs, such as a death in the family, by telegraph. It sometimes took several hours to send a telegram because it could only be done by standing in line at the post office. In the "old days" one sent a message across town by writing a note and giving it to a becak driver to deliver. Today, we communicate instantly across the city, the country and the world by SMS, for less that we paid the becake driver (in constant Rupiah). The changes have been so extensive that some of my students at both Gadjah Mada University (UGM) and the State Islamic University of Sunan Kalijaga (UINSK) are shocked to learn that I can remember times when there were no hand-phones, or Facebook or ATMs. The fact that the electronic communications revolution emerged in Yogya at approximately the same rate it has in the "developed" world is an indicator of the degree to which globalisation has diminished the gap between rich and poor countries. I should add here that electronic communication, especially e-mail, has revolutionised research. Thirty years ago anthropological fieldwork was generally conducted in isolation. Today it is possible to maintain communication with colleagues across the world, share ideas and information even from villages that would

${ }^{2}$ For an extended discussion of the ways in which the New Order regime attempted to guide the course of Indonesia's economic, political and cultural development see: J. Bresnan, Managing Indonesia: The Modern Political Economy (New York: Columbia University Press, 1993).

${ }^{3}$ Mark Woodward, Java, Indonesia and Islam (Heildelberg etc.: Springer, 2010). 
have formerly been considered remote and isolated thirty years ago. The implications for the ways in which these developments influence the research process have yet to be explored in the theoretical and methodological literature.

The rapid expansion of the translation and publication sectors has also contributed to the amounts of information available to Indonesian consumers. In the late 1970s the Gunung Agung near the southwest corner of the Tugu was the only bookstore of any size in Yogyakarta and its offerings were limited. Today people can choose from vast range of books by Indonesian, Western and Middle Eastern authors. Books are, of course, not the only media through which ideas are communicated. In the late 1970s audiotapes were already an important medium for the dissemination of ideas. Non-print media have expanded enormously. Audiotape remains a significant medium and has been augmented by video, $C D$ and access to information via the internet. These media, at least as much as print materials, have created an increasingly globally integrated information environment. It is important to emphasise that these media are culturally, religiously and politically neutral. In contrast to what Marshall McLuhan observed, the medium is not the message. The content of the Indonesian language Islam web, for example, mirrors that of other modes of discourse almost exactly. ${ }^{4}$

The explosion of the motorised transport system had a similarly significant impact on social networks. In the 1970s Yogyakarta was still a city of bicycles. Cars and motorcycles were very rare. There were perhaps a dozen taxis in the city most of which were parked at the railway station much of the time. Inter city transport was primarily by train or bus. Horse and bullock carts were common. There were very limited flights from Adisutjipto, which at that time was not an international airport. Today Air Asia boasts the "Everyone can fly." That is not actually true, but the number of air passengers is many times what it was thirty years ago. What in English are called motorcycles were formerly called sepeda-motor or motorised bicycles and now are simply "motor." This linguistic change

${ }^{4}$ H. Davulcu, S. Ahmed, S. Gokalp, H. Temkit, T. Taylor, M. Woodward, A. Amin, "Analyzing Sentiment Markers Describing Radical and Counter-Radical Elements in Online News," Proceedings of the 2nd IEEE International Conference on Social Computing (SocialCom-10), Symposium on Social Intelligence and Networking (SIN-10), Minneapolis, MN, August 2010, pp. 335-340. 
reflects the normalisation of motorised transport.

Technological development and the increasing availability of transport and communication have both broaden social networks and vastly increased the amount of information that can flow through them. Facebook is an obvious example because it enables very large networks of "friends" some to share almost unlimited amounts of information. My hypothesis is, however, that the technological developments that have had the greatest impact are hand phones and "motor" because they are inexpensive and very common. They make it easier for dispersed communities, especially people who have migrated from rural to urban areas, and the increasing numbers who now work overseas to remain in contact with friends and families. They also facilitate the development and expansion of networks based on cultural and religious affinities.

\section{Education}

Changes in education are equally apparent. This is especially true of higher education. In the early decades of post-coloniality Indonesia made enormous progress in expanding basic literacy. There has been a natural expansion of secondary and post-secondary education. These reflect a developing economy's requirement for an increasingly sophisticated labour force. Two educational developments are especially significant. These are the development of the Islamic Universities and the more recent emergence of extremely expensive secular and religious "international class" primary and secondary schools. Ironically these serve opposite ends of the economic spectrum. Islamic Universities offer educational opportunities to young people from rural, less developed communities. "International class" schools target the bureaucratic and capitalist elite. The emergence of the Islamic Universities may in the long term broaden the cultural and religious base of the middle class. The development of Islamic Universities is can also be seen as an outgrowth in changes in pesantren (traditional Islamic boarding schools). Over the past thirty years the number of these schools that teach "secular" subjects in addition to the traditional religious curriculum has increased significantly. This

${ }^{5}$ On the pesantren tradition see A. Djajadiningrat, "Reminiscences about Life in a Pesantren," in C. Penders (ed. and trans.), Indonesia: Selected Documents on Colonialism and Nationalism, 1830-1942 (Saint Lucia: University of Queensland Press, 1977), pp. 
has created a large cadre of young people from conservative Muslim backgrounds prepared for university study. The Islamic Universities are making important contributions not just to education in religious and secular subjects but also the expansion of the Muslim middle class. The emergence of elitist education may have nearly opposite sociological consequences if it establishes elite education, beyond the reach of all but a tiny minority, as a "gate keeper" for social advancement as it is in the United Kingdom and to a slightly lesser degree in the United States.

\section{Categorical Shifts: Agama (Religion) and Kebudayaan (Culture)}

Technological change and development in education are not difficult to document. They are what sociologist Emile Durkheim called "social facts." Assessing their social and cultural significance is a more problematic endeavour. This is an interpretive process that requires attention to the role of the state in shaping social and economic change. The cultural and religious landscapes and understandings of the relationship between culture and religion have shifted in opposite directions simultaneously in responses to technological change, enhanced communication and patterns of state power over the past three decades. The cultural-religious polarisation characteristic of the 1960s and 1970s has decreased significantly. Organised groups, such as Nahdlatul Ulama (NU) and Muhammadiyah and broader religious communities who were once overtly hostile have gradually come to see themselves as being

248-52; Z. Dhofier, The Pesantren Tradition: The Role of the Kyai in the Maintenance of Traditional Islam in Java (Tempe: Arizona State University Program for Southeast Asian Studies Monograph Series, 1999); and S. Yunanto et al., Islamic Education in South and South East Asia: Diversity, Problems and Strategy (Jakarta: RIDEP Institute, 2005). On the modernisation of the pesantren tradition see: Ronald Lukens-Bull, A Peaceful Jihad. Negotiating Identity and Modernity in Muslim Java (New York: Palgrave Macmillan, 2005), and "Round Table on Pesantren Tradition," in M. Pye et al. (eds.), Religious Harmony: Problems, Practice, and Education (Berlin: De Gruyer, 2006). On Muhammadiyah schools see: A. Azra, D. Afrianty, and R. Hefner, "Pesantren and Madrasa: Muslim Schools and National Deals in Indonesia," in R. Hefner and M. Zamman, Schooling Islam: the Culture and Politics of Modern Muslim Education (Princeton: Princeton University Press, 2007), p. 172-198.

${ }^{6}$ On the Durkheimian concept of social facts see M. Gilbert, On Social Facts (Princeton: Princeton University Press, 1989), pp. 237-288, and E. Durkheim, Rules of Sociological Method (New York: The Free Press, 1982). 
variants on common cultural religious themes. ${ }^{7}$ There has also been significant "santrification" or increased concern with orthoprax Muslim piety among groups who were formerly indifferent or even opposed to it. The public display and use of Muslim symbols, especially "Muslim" clothing for both women and men is also increasingly important.

In the late 1970's the heavy hands of colonialism and of the politicide of 1965 and 1966 that brought the New Order to power were readily apparent in Yogyakarta. There was a much strong correspondence between social communities and religious orientations than there is today. This was in part the consequence of colonial policies of "divided and rule" and of the political polarisation of religion in the first two decades of Indonesian history. There was a tendency to emphasise difference and to minimise commonality. One of the cornerstones of Dutch colonial policy had been to break links between what Kumar refers to as the two poles of Javanese civilisation: the kraton and the mosque. ${ }^{8}$ Through both coercion and elite education that focused on a modern, western curriculum and elements of Javanese culture that are not obviously Muslim, the Dutch sought to create an administrative elite that was western oriented and marginally committed to Islam. ${ }^{9}$ This policy was remarkably successful in the short run. In the late 1970s there was a noticeable educational divide in Yogyakarta. There were few observant Muslims, those known in the academic literature as santri, who were well educated in the modern sense. To complicate matters further there was a significant educational gap within the santri community because "modernist," especially those associated with Muhammadiyah and Persatuan Islam, had a substantial advantage when it came to "modern" learning. Similarly few members of the political elite had more than the most rudimentary knowledge of orthoprax Islam. Many, perhaps most, did not fast or pray and could

${ }^{7}$ On NU see: G. Barton and G. Fealy (eds.), Nahdlatul Ulama, Traditional Islam and Modernity in Indonesia (Clayton: Monash Asia Institute, 1996). On Muhammadiyah see: M. Nakamura, Over the Banyan Tree: A Study for the Muhammadiyah Movement in an Indonesian Town (Athens: Ohio University Press, 1983), and J. Peacock, Muslim Puritans, Reformist Psychology in Southeast Asia (Berkeley: University of California Press, 1978).

${ }^{8}$ A. Kumar, "Javanese Court Society and Politics in the Late Eighteenth Century: The Record of a Lady Soldier. Part I: The Religious, Social, and Economic Life of the Court," Indonesia 29, 1980, pp. 1-46.

${ }^{9} \mathrm{H}$. Sutherland, The Making of a Bureaucratic Elite: The Colonial Transformation of the Javanese Priyayi (Canberra: The Asian Studies Association of Australia, 1979). 
barely recite al-Fatiḩa (the first sura of al-Qur'an). They were ritually dependent upon, but socially distant from, santri ritual specialists who had these skills.

This bifurcation contributed to a cultural and religious divide between traditionalist Javanese and modernist Muslim elites because Muslim modernists are inclined to reject what M. C. Ricklefs calls the "mystic synthesis" and to have what Clifford Geertz refers to as a "scripturalist" religious orientation that is highly critical of local forms of Muslim culture and piety. ${ }^{10}$ Yogyakarta was an unusual, and nearly unique case, because the Muslim religious elite was drawn largely from Muhammadiyah. The political centre of Yogya was, and to a lesser extent remains, the kraton. Sociological this led to a paradoxical interdependence. Traditional Javanese elites relied on Muhammadiyah ritual specialists to perform weddings, funerals, circumcisions and other life crisis rituals. The Grand Mosque was, and still is, the symbolic centre of both Muhammadiyah and of the Yogyakarta kraton. Because Yogya was the first place that I experience the life of Muslim communities, I did not realise how exceptional this social and ritual system was. At that time some mystical organisations (aliran kepercayaan) were rejected "Islam" and "Muslim" as self designations and were certain that the Indonesian state was recognise them as self sufficient religions. This, of course, did not happen.

Considering shifts in usages and meanings of the terms agama and kebudayan helps us to understand these processes. Agama and kebudayan can only be roughly translated as religion and culture. ${ }^{11}$ Academic study of these concepts is complicated by the fact that they figure significantly in Indonesian political and religious discourse. They are simultaneously emic (meaningful) and etic (analytic) categories. The issues are further

${ }^{10}$ C. Geertz, Islam Observed: Religious Development in Morocco and Indonesia (Chicago: The University of Chicago Press, 1968), M. Ricklefs, Mystic Synthesis in Java: A History of Islamization from the Fourteenth to the Early Nineteenth Centuries (Norwalk, CT: East Bridge Books, 2006).

${ }^{11}$ For an analysis of the semantic of and politics concerning the category agama see: S. Hidayah, Religion in the Proper Sense of the Word: The Discourse of Agama in Indonesia, unpublished MA thesis, Center for Religious and Cross-Cultural Studies, Gadjah Mada University, 2007. A similar deconstruction of the category kebudayaan could be equally revealing. 
complicated by the fact that Indonesian political and religious discourse is more heavily informed by trans-national academic discourse than is the case in most other countries.

In some societies "religion" is not a salient emic category, or at least was not until it was introduced as such in colonial or neo-colonial contexts. This seems to be the case in Japan and among most American Indian People. ${ }^{12}$ Many Japanese, for example, are convinced that they do not have a religion because "religion" is defined as exclusive adherence to a particular sectarian group. ${ }^{13}$ In the American Southwest many Navajo people call what non-Indian people would call their "religion" simply the "Navajo way" and use the term religion to refer to varieties of Christianity, Islam, Buddhism and other trans-cultural religions with which they are familiar. In places where religion and culture are salient categories, and Indonesia is one of them, their boundaries are permeable and shift over time.

Questions of what is "religion" and what is "culture" may, at times, be bitterly contested. In the 1970s much of what I have written about over the years: the slametan, kraton ritual, and traditional healing for example, were often referred to as "Javanese Religion" (Agama Jawa). Prior to the advent of Muslim modernism, with its puritanical inclinations, in the early years of the twentieth century, and among individuals untouched or untroubled by this development, this complex on knowledge and praxis was, and still is, simply "Islam." Today the prayer meals, traditional medicine and palace rituals are much more commonly referred to as "Javanese Culture" (Kebudayaan Jawa) even though the nature of these phenomena have not changed substantially, no matter what one calls them. This reflects the diminution of religious polarisation over the past thirty years, and a strategy for avoiding it. Many proponents of what was formerly called Javanese Religion are now willing to accept the designation Javanese Culture to avoid antagonising orthoprax, and

${ }^{12}$ I use the term Indian rather than the more politically correct "Native American" because my Pima and Navajo friends in Arizona prefer to be called "Indian People."

${ }^{13}$ I would like to thank Professor James Foard of the Department of Religious Studies at Arizona State University for this observation. 
especially modernist and Islamist, Muslims. ${ }^{14}$

The logic of this semantic shift is that if these practices are defined as being not religious they are also not heresy. This strategy does not always work. In October of 2008 the Islamist Front Pembela Islam/FPI (Front for the Defense of Islam) attacked the headquarters of Javanist kebudayaan groups they considered to be "un-Islamic." In Yogyakarta they targeted the modernist mystical organisation Sapta Dharma, which, analytically speaking is a religious organisation but does now refer to itself as such. Periodic attacks against symbols of Kebudayaan Jawa, including wayang (shadow play) performances have continued. In 2011 the kraton supported two "cultural festivals" to demonstrate support for Javanese culture and opposition to violence inspired by exclusivist religious convictions. Both were staged on the alun alun (square) in front of the palace. One re-enacted "cultural performances" representative of each of the kebupaten (districts) in the Province/Sultanate, including pilgrimages to the graves of local saints. The other was a wayang festival that lasted for eleven nights and celebrated the $500^{\text {th }}$ anniversary of Sunan Kalijaga, the saint revered for his use of kebudayan as a vehicle for spreading Islamic teachings.

Similarly, many orthoprax Muslims have sought to describe this complex as "Javanese Islamic Culture" or simply "Javanese Culture" for similar reasons. Shifts in the boundaries between "culture" and "religion," can have important consequences for understanding the dynamics

${ }^{14}$ A similar dynamic tension can be found in many Indonesian Christian societies. Ambon is a particularly striking and complex example. There is a distinction between Kristen Ambon or Ambonese Christianity and Kristen Belanda or Dutch Christianity. Kristen Ambon includes many elements of traditional belief and ritual practice. Kristen Belanda is a more "orthodox" form of Dutch Calvinism. Kristen Ambon is practiced and supported exclusively by native Ambonese. During the colonial period Dutch missionaries discouraged this hybrid form of Christianity. Today Kristen Belanda is supported by Ambonese ministers who have studied in the Netherlands and by the large diaspora community most of who migrated the Netherlands in the 1950s because of their support for the Dutch during the Indonesian Revolution. Ambonese Christians consider them to be "imperialists" or "colonialists." This closely resembles the way in which many traditional Javanese Muslims think of Islamists affiliated with Saudi Arabian and other Wahhabi groups. On Wahhabi colonialism see M. Woodward, "Contesting Wahhabi Colonialism in Yogyakarta," COMOPS Journal: Analysis, Commentary and News from the World of Strategic Communications, November, 2008, pp. 1-8. 
of power in Javanese and Indonesian society. The Yogyakarta kraton now routinely refers to itself as a "centre of Javanese culture." 15 Here Kebudayan Jawa and Kebudayaaan Yogyakarta, refer not only to the fine and performing arts, and to things that anthropologists would typically refer to as culture, but also to elements of Javanese culture that scholars would generally consider to be religion, and that Javanese understand as being highly charged with power (kesekten). These include state ceremonies, pilgrimages to graves and other sacred places, traditional medicine, and the veneration of sacred heirlooms (pusaka) whose powers are so great that they can be fatal. Thus when the kraton describes itself as a "Centre of Kebudayaan" it is making very significant claims about its religious (in the analytic sense) legitimacy.

Many Javanese and other Indonesian intellectuals now blame the cultural/religious polarisation of earlier periods of post-colonial Indonesian history on the divide and rule policies of the Dutch and the research of Orientalists, Colonialist and Neo-Colonialist Anthropologists and Historians. Even the neo-fundamentalist journal Panjimas published a special issue describing the Islamic character of aspects of Javanese Culture that in the late 1970s it would have denounced in the harshest possible terms. ${ }^{16}$ One of the points made in this issue was that Orientalists had attempted to divide Indonesians by emphasising the non-Muslim elements of Javanese and other Indonesian cultures. Curiously some of my own works, especially those that have appeared in Indonesian translation, are sometimes cited in this discourse. ${ }^{17}$ Some people now

${ }^{15}$ This is, of course, a hegemonic discourse that is strongly contested by the neighboring court of Surakarta, which also claims to be the center of Javanese culture. The intensity with which these rival claims remain contested became clear to me in January of 2008 when I delivered an address at ceremonies inaugurating the Center for the Study of Religion and Javanese Culture at the National Higher School of Islamic Studies in Surakarta in which I spoke primarily about Yogyakarta. The audience, of approximately 300 found this more than a bit disturbing. Several pointed out that "Surakarta is the older of the two kingdoms and the real center of Javanese culture." Both claims are contested because in Yogyakarta it is believed that Surakarta ceased to be a genuine kingdom when Ngajogjokarto Hadiningrat was established. It is also contested by Javanese living out side the territories of both kingdoms.

${ }^{16}$ Panjimas vol. 1, no. 12, May 2007.

${ }^{17}$ Throughout the issue of Pajimas cited above and particularly in the editor's introduction to most recent edition of the Indonesian translation of Islam in Java 
read them as inclusivist Muslim theology. That was not my intent, but authors have no control over how their works are read and interpreted.

\section{E. Concluding Remarks}

The emergence of this apparent cultural-religious convergence does not, however, mean that relationships between agama and kebudayaan have reached a point of stable equilibrium. The lines of conflict have shifted because of the emergence of neo-Wahhabi Islamist groups supported by the Saudi state and private foundations in Saudi Arabia and elsewhere in the Middle East who seek to replace even the most Islamic forms of Javanese culture with what they consider to be the sunna or social practice of the Prophet Muhammad and his close companions. They see themselves as proponents of "pure" Islam. Abu Bakar Ba'aysir, who is perhaps Indonesia's most prominent Islamist thinker made exactly this point in a Ramadan speech in 2009 . He stated that he had nothing against Javanese culture, other than the ninety per cent of it that is polytheism (shirk). To return to the subject of communications technology, I recorded his remarks on my hand phone. Ba'asyir and his supporters think of themselves as the only genuine Muslim in Java. Many other Javanese call them Arab, Saudi or Wahhabi "colonialists" bent on destroying kebudayaan lokal (local culture). Today there are some people in Yogyakarta who think that to be Muslim is to mimic Arab culture, and at the same time there are many more who assert that one can be profoundly Javanese and profoundly Muslim at the same time. Part of what this tells us is that the discourse concerning the definition of agama and kebudayaan is an aspect of Javanese culture and religion though which difference and similarity are alternatively contested and managed.

(Islam Jawa, Yogyakarta: LKiS, 2006) in which the book is compared with Edward Said's Orientalism for exposing the anti-Islamic biases of Anglo-Dutch Orientalism and American Anthropology. In Indonesia the book is frequently read as inclusivist Islamic theology. Mitso Nakamura's works are described in similar ways. 


\section{BIBLIOGRAPHY}

Azra, A., D. Afrianty, and R. Hefner, "Pesantren and Madrasa: Muslim Schools and National Deals in Indonesia," in R. Hefner and M. Zamman, Schooling Islam: the Culture and Politics of Modern Muslim Education, Princeton: Princeton University Press, 2007.

Barton, G., and G. Fealy (eds.), Nabdlatul Ulama, Traditional Islam and Modernity in Indonesia, Clayton: Monash Asia Institute, 1996.

Bresnan, J., Managing Indonesia: The Modern Political Economy, New York: Columbia University Press, 1993.

Davulcu, H., S. Ahmed, S. Gokalp, H. Temkit, T. Taylor, M. Woodward, A. Amin, "Analyzing Sentiment Markers Describing Radical and Counter-Radical Elements in Online News," Proceedings of the 2nd IEEE International Conference on Social Computing (SocialCom-10), Symposium on Social Intelligence and Networking (SIN10), Minneapolis, MN, August 2010.

Dhofier, Z., The Pesantren Tradition: The Role of the Kyai in the Maintenance of Traditional Islam in Java, Tempe: Arizona State University Program for Southeast Asian Studies Monograph Series, 1999.

Djajadiningrat, A., "Reminiscences about Life in a Pesantren," in C. Penders (ed. and trans.), Indonesia: Selected Documents on Colonialism and Nationalism, 1830-1942, Saint Lucia: University of Queensland Press, 1977.

Durkheim, E., Rules of Sociological Method, New York: The Free Press, 1982.

Geertz, C., Islam Observed: Religious Development in Morocco and Indonesia, Chicago: The University of Chicago Press, 1968.

Gilbert, M., On Social Facts, Princeton: Princeton University Press, 1989. Hidayah, S., Religion in the Proper Sense of the Word: The Discourse of Agama in Indonesia, unpublished MA thesis, Center for Religious and CrossCultural Studies, Gadjah Mada University, 2007.

Kumar A., "Javanese Court Society and Politics in the Late Eighteenth Century: The Record of a Lady Soldier. Part I: The Religious, Social, and Economic Life of the Court," Indonesia 29, 1980.

Lukens-Bull, Ronald, "Round Table on Pesantren Tradition," in M. Pye 
et al. (eds.), Religious Harmony: Problems, Practice, and Education, Berlin: De Gruyer, 2006.

Lukens-Bull, Ronald, A Peaceful Jihad. Negotiating Identity and Modernity in Muslim Java, New York: Palgrave Macmillan, 2005.

Nakamura, M., Over the Banyan Tree: A Study for the Mubammadiyah Movement in an Indonesian Town, Athens: Ohio University Press, 1983.

Panjimas vol. 1, no. 12, May 2007.

Peacock, J., Muslim Puritans, Reformist Psychology in Southeast Asia, Berkeley: University of California Press, 1978.

Ricklefs, M., Mystic Synthesis in Java: A History of Islamization from the Fourteenth to the Early Nineteenth Centuries, Norwalk, CT: East Bridge Books, 2006.

Soemarjan, S., Social Changes in Yogyakarta, Ithaca: Cornell University Press, 1962.

Sutherland, H., The Making of a Bureaucratic Elite: The Colonial Transformation of the Javanese Priyayi, Canberra: The Asian Studies Association of Australia, 1979.

Woodward, Mark, "Contesting Wahhabi Colonialism in Yogyakarta," COMOPS Journal: Analysis, Commentary and News from the World of Strategic Communications, November, 2008, pp. 1-8.

----, Java, Indonesia and Islam, Heildelberg etc.: Springer, 2010.

Yunanto, S., et al., Islamic Education in South and South East Asia: Diversity, Problems and Strategy, Jakarta: RIDEP Institute, 2005. 